\title{
Legal Aspect of Micro and Small Enterprises (MSEs) in Rural Areas
}

\author{
Rino Adibowo \\ Universitas Komputer Indonesia \\ Bandung, Indonesia \\ rino.adibowo@email.unikom.ac.id
}

\begin{abstract}
Small and Micro Enterprises (MSEs) in rural areas aims to know and analyze how MSEs knowledge in rural areas about the legal aspects. To know and analyze how the desire of MSEs in rural area in its development of MSEs in order to improve rural economy. The normative juridical approach method, which is a study that emphasizes research on bibliography or secondary data covering primary legal materials, namely legislation, international conventions, empowerment materials and secondary law, that is materials that can help analyze and understand materials primary law. MSEs can not be implemented maximally, due to limited capital owned by the actors of MSEs so as to affect the production. Capital assistance from the government is not evenly distributed, even many people who have micro and small enterprises do not know about the fund / capital aid for business development, meaning that there is still minimal socialization done by the government. Limited human resources, marketing management is traditional, budget is not fair and equitable, legal protection / legality principle is still not maximal. In response, the government needs to provide funds/budgets of micro and small enterprises assistance, and assist the community in terms of legality principles.
\end{abstract}

Keywords - Empowerment, Legality Principles, Micro and Small Enterprises

\section{INTRODUCTION}

Village empowerment is part of community empowerment which has meaning process to build mindset and competence of village community. Therefore the priority of the use of village funds for programs and activities in the field of Village Community Empowerment, is allocated to fund activities aimed at improving the capacity of villagers in developing entrepreneurship, increasing income, and expanding the economic scale of individual citizens or community and village groups, among others:

a. Increased rural economic investment through the procurement, development or assistance of production equipment, capital, and capacity building through training and apprenticeship;

b. Support of good economic activities developed by BUM Desa or BUM Desa Bersama, as well as by other groups and or economic institutions of the village community;

c. Capacity building support for Village food security programs and activities;

d. Community organizing, facilitation and paralegal training and legal assistance of the village community, including the establishment of Village Community Empowerment Cadres/ Kader Pemberdayaan Masyarakat Desa (KPMD) and capacity building of the Community Learning Center (Community Center); e. Promotion and public health education as well as and availability or functioning of medical personnel / swamedikasi in village;

f. Support to Forest / Coastal Forest Management and Forest / Coastal Community Activities;

g. Capacity building of community groups for renewable energy and environmental conservation; and / or

h. Other areas of economic empowerment activities in accordance with the analysis of village needs and have been defined in the Village Deliberations.

Generally empowerment is a process and goal to be empowered in various areas of life. As a process, empowerment is a series of activities to strengthen the power or empowerment of weak groups in society, including individuals who experience poverty.

Sudrajat[1] argues that empowerment will produce a dynamic and progressive society on an ongoing basis, because it is based on the existence of intrinsic motivation within them. Further Sudrajat[2] states that:

Empowerment is an effort to improve the level of society and the human person, this effort includes: (1) encouraging, motivating, raising awareness and potential and creating a climate / atmosphere to develop; (2) strengthening the power, potential possessed by positive steps; and (3) provision of inputs and access to opportunities for adaptation.

Empowerment is an attempt to recognize, understand policy and harness the power, investigate the processes by which citizens can organize or control (control over) their lives, skills and position to be critical and effective participants in society, including changing that power.

Sociologically, the empowerment of society is the giving of powerless power, because by having their power squeezed in powerlessness will be able to carry out the process of actualization and existence itself. Structurally, humans do need to be given the opportunity to actualize their existence (self-actualization), since self-actualization is a basic human need.

Based on the opinions expressed above, it can be seen that empowerment contains two meanings. First, it emphasizes the process of giving some power, strength or ability to the community to make them more empowered. Second, it emphasizes the process of encouraging or motivating people to have the ability to determine what their life choices are. Reference[3] suggests that:

Empowerment refers to the ability of people, especially vulnerable and vulnerable groups so that 
they have the power or ability to a) meet their basic needs so that they have freedom (fredom), in the sense not only free to express opinions, but free from hunger, free of ignorance, free from pain, b) reach out to productive resources that enable them to increase their incomes and obtain the goods and services they need; and c) participate in the development process and decisions that affect them.

Based on the opinions expressed above, we can see that empowerment is more emphasized to the ability of a person especially for the weak group so that they have the power in order to meet the needs of life, and can participate in development processes that affect their lives. According to Ife as quoted by Suharto (2005: 59) in his book entitled Membangun Masyarakat Memberdayakan Rakyat argued that:

Empowerment contains two key definitions, namely power and the weak group. Power here means not only about political power in the narrow sense, but the power or mastery of the client over:

a. Personal choices and life opportunities: the ability to make decisions about lifestyle, shelter, occupation.

b. Defining needs: the ability to determine needs in harmony with aspirations and desires.

c. Ideas or ideas: the ability to express and contribute gagsan in a forum or discussion freely and without pressure.

d. Institutions: the ability to reach, use and influence the institutions of society, such as social welfare institutions, education, health.

e. Resources: the ability to mobilize formal, informal and social resources.

f. Economic activity: the ability to utilize and manage the mechanisms of production, distribution and exchange of goods and services.

g. Reproduction: ability in relation to childbirth, child care, education and socialization.

(Suharto, 2005: 59)

Community empowerment is basically a process that shows the existence of a series of activities, steps or actions performed systematically and terpogram that describes the existence of efforts to change the individual, the community is less or not empowered to empowerment, by giving or diverting power, ability, strength. This means there are two related parties, the first empowering and the second empowered.

One area of empowerment of rural communities is the empowerment in the economic field, including the development of Micro and Small Enterprises (MSEs) located in rural areas.

Micro and Small Enterprises (MSEs) has shown a stretch in building the national economy. Imagine, nowadays more and more creative capital-financing businesses have sprung up. The legal basis of MSME in Indonesia's positive law is Law Number 20 Year 2008 About Micro, Small and Medium Enterprises. The national provisions contain the definition of Micro, Small and Medium Enterprises and the criteria of what is included in small and medium enterprises.

Micro and Small Business as stipulated in Law Number 20 Year 2008 regarding Micro, Small and Medium
Enterprises (MSMEs), have different capital. Based on Article 6 paragraphs (1) and (2), Micro Enterprises have net assets of Rp 50,000,000 (fifty million rupiah) excluding land and building of business premises, or have annual sales of Rp. 300,000,000.00 (three hundred million rupiah).

While Small Business criteria is to have a net worth of more than Rp. 50,000,000.00 (fifty million rupiah) up to a maximum of Rp. 500,000,000.00 (five hundred million rupiah) excluding land and building of business premises or having annual sales proceeds of more than Rp. $300,000,000.00$ (three hundred million rupiah) up to a maximum of Rp. 2.500.000.000,00 (two billion five hundred million rupiah).

Micro and Small Business is one of the most important parts in empowering the village community, but also by increasing the existence of Small and Medium Enterprises can help advance the economy of a country. Even stated that if the number of MSEs will continue to survive from year to year, then the contribution provided by MSEs MSES will also increase to advance the Indonesian economy. However, the development of MSEs in various regions currently experiencing various obstacles, the problems faced by MSEs are as follows:

a. Lack of capital, since capital is obtained from the money of the business owner himself;

b. Difficulties in marketing, less use of information technology media in marketing their products;

c. Simple organizational structure with non-standard division of labor;

d. The quality of management is low;

e. Natural resources and human resources are limited;

f. Do not have complete and accurate financial report;

g. Legality aspect is weak;

h. Low use of technology;

i. Less improving the look of the product.

These problems inhibit the growth of Micro and Small Enterprises located in rural areas. This is seen when researchers conduct a survey to the field, where many of the business actors who are in rural areas have obstacles, especially in the aspect of the legality of their business.

Similar abaout growth of Micro and Small Enterprises in Southern Africa McPherson, Michael A. "Growth of micro and small enterprises in southern Africa." Journal of development economics 48.2 (1996): 253-277[16]

\section{METHOD}

In this study, researchers used the following methods: The approach method used is a normative juridical approach, which is a study that emphasizes research on library material or secondary data, which includes:

a. Primary legal materials, namely legislation, international conventions.

Primary legal material consists of positive legal norms, namely:

1. Law Number 20 of 2008 concerning Micro and Small and Medium Enterprises.

2. Presidential Regulation No. 98 of 2014 concerning Licensing for Micro and Small Businesses. 
3. Regulation of the Minister of Trade of the Republic of Indonesia No. 36 / M-Dag / Per / 9/2007 concerning the Issuance of Trading Business Permits for Trading Business Permits (SIUP)

4. Government Regulation of the Republic of Indonesia Number 17 of 2013 concerning Implementation of Law Number 20 of 2008 concerning Micro, Small and Medium Enterprises

5. PP No. 44 of 1997 concerning Partnership

6. PP No. 32 of 1998 concerning Development and Development of Small Businesses

7. Presidential Instruction No. 10 of 1999 concerning Empowering Medium Enterprises

8. Presidential Decree No. 127 of 2001 concerning Business Fields / Types Reserved for Small Businesses and Business Fields / Types Opened for Medium or Large Businesses with Partnership Requirements

9. Presidential Decree No. 56 of 2002 concerning Restructuring of Small and Medium Business Loans

10. Minister of State-Owned Enterprises' Regulation Per-05 / MBU / 2007 concerning Partnership Programs of State-Owned Enterprises with Small Businesses and Community Development Programs

11. Minister of State-Owned Enterprises Ministerial Decree No. 05 / MBU / 2007 concerning Partnership Programs for State-Owned Enterprises [5-15]

b. Empowerment materials and secondary law, namely materials that can help analyze and understand primary legal materials, such as research results, scientific works in the form of books, journals, papers and other literature whose substance is relevant to this research.

c. Empowerment and tertiary law materials, which are materials that provide information about primary and secondary legal materials, such as legal dictionaries (Black's Law Dictionary).

In this study, testing and reviewing secondary data relating to village empowerment through the MSME legality program, and at this stage grammatically interpreted that is interpreting the words of the relevant legislation, systematic interpretation of the law by linking legislation that one with other legislation, authentic legal interpretation that can be done by looking at the explanations of the legislators themselves.

The research carried out is analytical descriptive, which describes the instruments of community empowerment, national and international law associated with theories of community empowerment, law and practice of its implementation relating to the object of research. The description involves the facts systematically in the form of secondary data of primary legal materials, namely laws, government regulations, secondary data of secondary legal materials, namely opinions of experts (doctrine) relating to village empowerment through MSME legality programs, as well as secondary data on tertiary legal materials like a dictionary of government, politics, and law.

Similar with Employee Relative in Small Firms: A MicroBusiness Perspective Matlay, Harry. "Employee relations in small firms: A micro-business perspective." Employee relations 21.3 (1999): 285-295[17].
In this study data collection techniques were carried out in two stages, namely:

a. Library research (library research), in this case researchers conduct research on secondary data of primary legal materials in the form of legislation, as well as other related regulations. In addition, it also examines secondary data of secondary legal material in the form of scientific works of experts in the field of law and is supported by research on secondary data on tertiary legal materials.

b. Field research, in this case only as supporting data in research to support and complete literature studies, by conducting structured interviews with related parties. Informants in structured interviews related to the research were carried out to the village government and MSEs business actors in the villages that were the location of the study. The survey conducted by researchers was to visit the rural location of the study, then conduct meetings with the village officials following the MSEs found in the study location villages, conducting interviews with MSEs including the business fields and processes and constraints in the business undertaken, especially asking related aspects legality of the business concerned.

All data obtained were analyzed qualitatively juridically. In this case, the analysis is carried out by paying attention to the hierarchy of laws and regulations so that the laws and regulations do not conflict with other laws and the attainment of legal certainty.

The location of the study was conducted in several places including: Soreang Village, Soreang District, and Bandung Regency Government, as well as several websites in the internet system.

\section{RESULTS}

Lack of capital, because capital is obtained from the money of the business owner himself; capital assistance from the government has not been evenly distributed evenly, even there are still many people who have micro and small businesses do not know about funds / capital assistance for business development, meaning that there is still a lack of socialization carried out by the government.

Based on the results of research in the field, there are findings regarding the constraints faced by MSEs, namely regarding capital. The existence of these capital limitations can cause MSEs to not run optimally. The capital they use is private capital, meaning that there is no special capital / budget that they allocate to the development of the MSE. For example, Opak MSEs, the capital they use depends on personal financial conditions which ultimately affect the production of opaque produced.

And not only in the production stage, but also influence the purchase of raw materials for the manufacture of opaque which then affects the quality of the opaque produced is also not optimal. Actually the local government provides business capital assistance, but the business assistance capital is not absorbed maximally. This is caused by several factors, the lack of government socialization that is not comprehensive, internal knowledge (MSEs) that are still limited, data 
collection of MSEs that is not optimal, and the existence of certain priorities related to the community / recipients of MSEs assistance.

Difficulties in marketing, less use of the use of information technology media in marketing their products; there are limitations in marketing management, on average they only market their processed products in a conventional way and have not understood the use of media technology as a means to improve the quality of the marketing of the products it sells.

These obstacles occur, because marketing management is still using traditional methods. Still making limited sales, such as utilizing stalls around the house / residence of the MSEs manager, subscription kiosks, and relying on reservations for individuals or in a certain amount.The way of selling that is done is not able to use technology or onlinebased means, due to the limited knowledge of technology. In addition, some of the sample MSEs interviewed in terms of education and age were not optimal. As with the average education factor, they only graduated from advanced or equivalent levels of junior high school (SMP), which can then influence their knowledge of technology utilization.

Besides that, it is also due to age, they are on average elderly so that to understand technology is very limited. The local government has held training for those who are members of the MSEs, but the training has not been maximized in terms of results and benefits because the model of training / or socialization carried out has not adjusted to the real conditions of the community. Another thing is that it doesn't improve the appearance of the product; this factor is very important because the appearance of the cooking of the existing product is still simple, it is because of the limited capital, the ability to innovate, and the fear factor of the business manager in relation to profit and loss orientation.

Simple organizational structure with non-standard division of labor; because the business relies on its own capital, so for employees or those who work are still family members and the system is not yet professional, it is still done in a familial way and there is no division of labor based on expertise, almost as a whole optimizes the role of family or relatives.

MSEs conducted in rural communities certainly adjust to the conditions and characteristics of traditional communities, which of course has an influence on the way or style of work. Familiarity or reliance on kinship aspects is still carried out by rural communities in their daily lives, this is included in their working pattern. Therefore, business / business that is managed also utilizes kinship / kinship aspects, because in addition to their lack of understanding of professional division of labor, there is fear if they do the work by partnering or cooperating, such as fear of failure, tend to be ashamed and difficult to accept modern change because it certainly fits the characteristics of rural communities. In contrast to the characteristics of modern society / city, they are more receptive to social change and certainly affect the system of division of labor carried out with professional management.

Low quality management; this happens because there is no professional division of labor, small capital, so it affects the quality of management that only relies on conventional management, it also affects the quality of the products produced.
Weak aspects of legality; due to their lack of understanding of the legality of the products produced which resulted in their products not being able to compete widely, and certainly affecting the patents of the products produced. Rural communities are seen from the characteristics of their traditional community, which also influences their understanding of law / regulation / legality.

There are still many MSEs produced that are not officially registered, either trademarks or businesses that they manage, which makes them difficult / constrained in the face of market / market competition in the market. Their products experience problems to penetrate the market nationally, due to a lack of understanding of the legal aspects.

Even not only in terms of marketing, they are also constrained from business licenses. The business they initiated / built did not yet have an official letter from the government, which then also affected production, sales and even the public's trust in the product was questionable, it was because the product they produced had no label or business license and form other legalization.

Every person in the city of Bandung who wants to get a PKP certificate must register with the Bandung City Health Office. The Pharmacy Section and Health Supplies of the Bandung City Health Office will hold PKP 3-4 times a year or according to the available budget. Food extension certificates can be obtained by the applicant (either the owner or the business responsible) from other cities / regencies, because PKP is national. Therefore, if the applicant has not been successfully registered to take part in the PKP in the city where the business is domiciled (because the quota of participants has been fully filled), the applicant can proactively seek information and register PKP in another city. Examples of packaging label designs are also required to obtain SPP-IRT. Packaging labels can be paper, plastic stickers, or printed directly on a product wrap (like most labels on biscuit packaging and various other snacks). The regulations regarding label standards are in the form of packaging, which must contain at least information about the product name, list of ingredients used, net weight / content, IRTP name and address, production code (which contains the date of production), and number of Household Industry Food (P -IRT). The applicant needs to ensure that the label design has provided space to include the information.

If the scale of production has increased so that business actors need to have a larger production site - for example in the form of a separate building (outside the house) - then the business actor can no longer use the SPP-IRT as a circulation permit, but must start taking care of the distribution permit in the form of BPOM certification. Although the business scale is still at the level of SMEs (according to Law No. 20/2008 up to a turnover of Rp. 50 billion / year), as long as the production site is no longer at home, then every business actor becomes obliged to obtain BPOM certification for all food products.

Circular permission is attached to the type of product not a business entity. If the applicant produces several types of products from the same production facility, then the applicant needs to register all product variants produced so that the Health Service officer can provide a P-IRT number code that is appropriate for each product. This relates to 16 codes of food types that are allowed to obtain marketing permits in the form of SPP-IRT. 
Regarding the procedure for obtaining a halal certificate, the product of the business actor must be registered with the local LPPOM MUI to check the halalness. Products certified by LPPOM MUI West Java are reserved for small and medium entrepreneurs. While for large products must be registered with the central LPPOM MUI. For products that get facilities from the government, the fee is waived, while if you register yourself, you will be charged a fee.

After the business actor registers, then the MUI will assign the auditor to examine and review the product. The auditor will examine everything from raw materials, supplementary materials, production processes, distribution to presentation. In addition, the MUI will also conduct laboratory tests on these products. The results of the auditor will then be taken to the Fatwa Commission Session, if they pass the halal certificate will be given. Halal certificates can be given if each product is not mixed with unclean ingredients such as carcasses, blood, pork and animals slaughtered in names other than Allah. This halal certificate also has a validity period of 2 years, after which it must be extended again. Usually there is a notification letter 3 months before the time is up.

Both central and regional governments try to develop continuously on policies in the field of micro and small businesses. This is because the development of Micro, Small and Medium Enterprises can support national economic development. Current developments regarding micro and small businesses are related to the licensing process. The government decided to remove the licensing process for the establishment of micro and small businesses. Thus, business people who will establish a micro or small business simply register before starting a business. This policy aims to accelerate the growth of micro and small businesses in Indonesia. Regarding this matter, the government will revise Perpres No. 98 of 2014 concerning micro and small business licenses. Presidential Regulation No. 98 of 2014 concerning the authority of the Camat issued a small micro business license. Now that it is changed, no more permission is needed, just registered.

Micro and small businesses in the city of Bandung are currently not required to have SPP-IRT, only need a permit document for Micro Business Registration (TDUM) or Small Business Registration (TDUK). However, this has not been fully realized in the district of Bandung. this can be seen from the results of field research conducted by the research team. The research team's research subjects are related to the identification of the legality aspects of micro and small businesses, namely micro and small businesses located in Bandung regency precisely in Katapang District, Pangauban Village. Business actors who are the subject of research are opaque business actors and food processing business of pastries. The first business actor is an opaque businessman named Mr Iya Darya located in Babakan Cedok Number 27 RT 02 RW 10 Pangauban Soreang Village. The person concerned has carried out his business for more than 60 (sixty years), but until now has not been able to fulfill the legality aspects required by both the central and regional governments.

Based on the research team's research, the constraints faced by business actors are that there is no maximum empowerment from the local government, resulting in a lack of accurate information regarding legality management by business actors. At this time, Bapak Iya Darya has not submitted SPP-IRT (Household Food-Industry Production Certificate) and the legality of the Sign of Micro and Small Business Registration. The impact arising from the absence of SPT-IRT and halal labels is the lack of marketing expansion, where products from business actors cannot enter minimarkets and supermarkets. This of course affects the business profit.

The second business actor who is the research subject of the research team is a food processing business of pastries. The businessman was named Mr. Indra Suhanda, which was located in Kampung Bojong Buah RT 003 RW 001, Pangauban Village, Katapang District, Bandung Regency. Indra Suhanda's father is engaged in a business field that has been running for 4 (four) years.

Based on the study of the research team of the two business actors, it can be identified that there are still many micro and small business actors that have not been maximally empowered by the Regional Government, even though the potential of these business actors is very large and can advance the regional economy. The problems that are seen in the legality of business are that there is no accurate information from the local government regarding the management of business legality for micro and small business actors. Therefore, micro and small businesses in the region cannot know with certainty the obligations that must be carried out related to business legality and the benefits derived from fulfilling these legal aspects. This of course has an impact on the economic gain as well as the expansion in terms of marketing that cannot be done maximally.

Various provisions both from the central government and regional regulations have not been maximally socialized to micro and small businesses in the region. This is because legal counseling activities as well as legal socialization carried out only to a limited extent have not been maximally followed up with legal assistance in the management of the legality aspect.

Various actions can be taken to overcome the problems of business legality of micro and small business actors in the region, namely that there must be a synergistic action between the regional government and related parties. Efforts are being made to collect data from the sub-districts regarding business actors in their area for later data to be taken into consideration in the procurement of legal socialization as well as legal assistance in the aspect of business legality. The extension activities carried out by the local government are no longer centralized in the district government, but must be entered into the regions or held in village halls. This extension activity must also be followed up with ease in managing business actors in the region.

\section{DISCUSSION}

Based on the results of research in the field, there are findings regarding the constraints faced by MSEs, namely regarding capital. The existence of these capital limitations can cause MSEs to not run optimally. The capital they use is private capital, meaning that there is no special capital / budget that they allocate to the development of the MSE. For example, Opak MSEs, the capital they use depends on personal financial conditions which ultimately affect the production of opaque produced. 
And not only in the production stage, but also influence the purchase of raw materials for the manufacture of opaque which then affects the quality of the opaque produced is also not optimal. Actually the local government provides business capital assistance, but the business assistance capital is not absorbed maximally. This is caused by several factors, the lack of government socialization that is not comprehensive, internal knowledge (MSEs) that are still limited, data collection of MSEs that is not optimal, and the existence of certain priorities related to the community / recipients of MSE assistance.

Difficulties in marketing, less use of the use of information technology media in marketing their products; there are limitations in marketing management, on average they only market their processed products in a conventional way and have not understood the use of media technology as a means to improve the quality of the marketing of the products it sells.

These obstacles occur, because marketing management is still using traditional methods. Still making limited sales, such as utilizing stalls around the house / residence of the UMK manager, subscription kiosks, and relying on reservations for individuals or in a certain amount.

The way of selling that is done is not able to use technology or online-based means, due to the limited knowledge of technology. In addition, some of the sample MSEs interviewed in terms of education and age were not optimal. As with the average education factor, they only graduated from advanced or equivalent levels of junior high school (SMP), which can then influence their knowledge of technology utilization.

Besides that, it is also due to age, they are on average elderly so that to understand technology is very limited. The local government has held training for those who are members of the MSEs, but the training has not been maximized in terms of results and benefits because the model of training / or socialization carried out has not adjusted to the real conditions of the community. Another thing is that it doesn't improve the appearance of the product; this factor is very important because the appearance of the cooking of the existing product is still simple, it is because of the limited capital, the ability to innovate, and the fear factor of the business manager in relation to profit and loss orientation.Simple organizational structure with nonstandard division of labor; because the business relies on its own capital, so for employees or those who work are still family members and the system is not yet professional, it is still done in a familial way and there is no division of labor based on expertise, almost as a whole optimizes the role of family or relatives.

MSEs conducted in rural communities certainly adjust to the conditions and characteristics of traditional communities, which of course has an influence on the way or style of work. Familiarity or reliance on kinship aspects is still carried out by rural communities in their daily lives, this is included in their working pattern. Therefore, business / business that is managed also utilizes kinship / kinship aspects, because in addition to their lack of understanding of professional division of labor, there is fear if they do the work by partnering or cooperating, such as fear of failure, tend to be ashamed and difficult to accept modern change because it certainly fits the characteristics of rural communities. In contrast to the characteristics of modern society / city, they are more receptive to social change and certainly affect the system of division of labor carried out with professional management.

Low quality management; this happens because there is no professional division of labor, small capital, so it affects the quality of management that only relies on conventional management, it also affects the quality of the products produced.

Weak aspects of legality; due to their lack of understanding of the legality of the products produced which resulted in their products not being able to compete widely, and certainly affecting the patents of the products produced. Rural communities are seen from the characteristics of their traditional community, which also influences their understanding of law / regulation / legality.

There are still many MSEs produced that are not officially registered, either trademarks or businesses that they manage, which makes them difficult / constrained in the face of market / market competition in the market. Their products experience problems to penetrate the market nationally, due to a lack of understanding of the legal aspects.

Even not only in terms of marketing, they are also constrained from business licenses. The business they initiated / built did not yet have an official letter from the government, which then also affected production, sales and even the public's trust in the product was questionable, it was because the product they produced had no label or business license and form other legalization.

Every person in the city of Bandung who wants to get a PKP certificate must register with the Bandung City Health Office. The Pharmacy Section and Health Supplies of the Bandung City Health Office will hold PKP 3-4 times a year or according to the available budget. Food extension certificates can be obtained by the applicant (either the owner or the business responsible) from other cities / regencies, because PKP is national. Therefore, if the applicant has not been successfully registered to take part in the PKP in the city where the business is domiciled (because the quota of participants has been fully filled), the applicant can proactively seek information and register PKP in another city. Examples of packaging label designs are also required to obtain SPP-IRT. Packaging labels can be paper, plastic stickers, or printed directly on a product wrap (like most labels on biscuit packaging and various other snacks). The regulations regarding label standards are in the form of packaging, which must contain at least information about the product name, list of ingredients used, net weight / content, IRTP name and address, production code (which contains the date of production), and number of Household Industry Food (P -IRT). The applicant needs to ensure that the label design has provided space to include the information.

If the scale of production has increased so that business actors need to have a larger production site - for example in the form of a separate building (outside the house) - then the business actor can no longer use the SPP-IRT as a circulation permit, but must start taking care of the distribution permit in the form of BPOM certification. Although the business scale is still at the level of SMEs (according to Law No. 20/2008 up to a turnover of Rp. 50 billion / year), as long as the production site is no longer at home, then every business 
actor becomes obliged to obtain BPOM certification for all food products.

Circular permission is attached to the type of product not a business entity. If the applicant produces several types of products from the same production facility, then the applicant needs to register all product variants produced so that the Health Service officer can provide a P-IRT number code that is appropriate for each product. This relates to 16 codes of food types that are allowed to obtain marketing permits in the form of SPP-IRT.

Regarding the procedure for obtaining a halal certificate, the product of the business actor must be registered with the local LPPOM MUI to check the halalness. Products certified by LPPOM MUI West Java are reserved for small and medium entrepreneurs. While for large products must be registered with the central LPPOM MUI. For products that get facilities from the government, the fee is waived, while if you register yourself, you will be charged a fee.

After the business actor registers, then the MUI will assign the auditor to examine and review the product. The auditor will examine everything from raw materials, supplementary materials, production processes, distribution to presentation. In addition, the MUI will also conduct laboratory tests on these products. The results of the auditor will then be taken to the Fatwa Commission Session, if they pass the halal certificate will be given. Halal certificates can be given if each product is not mixed with unclean ingredients such as carcasses, blood, pork and animals slaughtered in names other than Allah. This halal certificate also has a validity period of 2 years, after which it must be extended again. Usually there is a notification letter 3 months before the time is up.

Both central and regional governments try to develop continuously on policies in the field of micro and small businesses. This is because the development of Micro, Small and Medium Enterprises can support national economic development. Current developments regarding micro and small businesses are related to the licensing process. The government decided to remove the licensing process for the establishment of micro and small businesses. Thus, business people who will establish a micro or small business simply register before starting a business. This policy aims to accelerate the growth of micro and small businesses in Indonesia. Regarding this matter, the government will revise Perpres No. 98 of 2014 concerning micro and small business licenses. Presidential Regulation No. 98 of 2014 concerning the authority of the Camat issued a small micro business license. Now that it is changed, no more permission is needed, just registered.

Micro and small businesses in the city of Bandung are currently not required to have SPP-IRT, only need a permit document for Micro Business Registration (TDUM) or Small Business Registration (TDUK). However, this has not been fully realized in the district of Bandung. this can be seen from the results of field research conducted by the research team. The research team's research subjects are related to the identification of the legality aspects of micro and small businesses, namely micro and small businesses located in Bandung regency precisely in Katapang District, Pangauban Village. Business actors who are the subject of research are opaque business actors and food processing business of pastries. The first business actor is an opaque businessman named Mr Iya Darya located in Babakan Cedok Number 27 RT 02 RW 10 Pangauban Soreang Village. The person concerned has carried out his business for more than 60 (sixty years), but until now has not been able to fulfill the legality aspects required by both the central and regional governments.

Based on the research team's research, the constraints faced by business actors are that there is no maximum empowerment from the local government, resulting in a lack of accurate information regarding legality management by business actors. At this time, Bapak Iya Darya has not submitted SPP-IRT (Household Food-Industry Production Certificate) and the legality of the Sign of Micro and Small Business Registration. The impact arising from the absence of SPT-IRT and halal labels is the lack of marketing expansion, where products from business actors cannot enter minimarkets and supermarkets. This of course affects the business profit.

The second business actor who is the research subject of the research team is a food processing business of pastries. The businessman was named Mr. Indra Suhanda, which was located in Kampung Bojong Buah RT 003 RW 001, Pangauban Village, Katapang District, Bandung Regency. Indra Suhanda's father is engaged in a business field that has been running for 4 (four) years.

\section{CONCLUSION}

Empowerment programs carried out by the government through micro and small businesses have not fully run optimally, this is due to several factors that can hinder the success of community empowerment. The factors in question are limited human resource capabilities (micro and small business actors), marketing management that is still traditional, the budget given by the government to the community is not yet fully fair and equitable, legal protection is still not maximal or things relating to the principle of legality.

\section{ACKNOWLEDGMENT}

The researcher would like to thank to LPPM Unikom as the research funder for the lecturers, to Mrs. Dr. Ir. Lia Warlina, M.Si as Director of Unikom's LPPM. And thanks also to the local government who have helped this research in obtaining research data, to all informants who have provided their data through interviews.

\section{REFERENCES}

[1] Priyono, S, Onny dan Pranaka A.M.W. Pemberdayaan Konsep Kebijakan dan Implementasi. Jakarta: Centre For Strategic And International Studies, 1996

[2] Suharto, Edi. Membangun Masyarakat Memberdayakan Masyarakat. Bandung: PT. Repika Aditama,

[3] Undang-Undang Nomor 18 Tahun 2012 Tentang Pangan

[4] Peraturan Pemerintah Nomor 28 Tahun 2004 Tentang Keamanan, Mutu dan Gizi Pangan

[5] Law Number 20 of 2008 concerning Micro and Small and Medium Enterprises.

[6] Presidential Regulation No. 98 of 2014 concerning Licensing for Micro and Small Businesses.

[7] Regulation of the Minister of Trade of the Republic of Indonesia No. 36 / M-Dag / Per / 9/2007 concerning the Issuance of Trading Business Permits for Trading Business Permits (SIUP) 
[8] Government Regulation of the Republic of Indonesia Number 17 of 2013 concerning Implementation of Law Number 20 of 2008 concerning Micro, Small and Medium Enterprises

[9] PP No. 44 of 1997 concerning Partnership

[10] PP No. 32 of 1998 concerning Development and Development of Small Businesses

[11] Presidential Instruction No. 10 of 1999 concerning Empowering Medium Enterprises

[12] Presidential Decree No. 127 of 2001 concerning Business Fields / Types Reserved for Small Businesses and Business Fields / Types Opened for Medium or Large Businesses with Partnership Requirements

[13] Presidential Decree No. 56 of 2002 concerning Restructuring of Small and Medium Business Loans

[14] Minister of State-Owned Enterprises' Regulation Per-05 / MBU / 2007 concerning Partnership Programs of State-Owned Enterprises with Small Businesses and Community Development Programs

[15] Minister of State-Owned Enterprises Ministerial Decree No. 05 / MBU / 2007 concerning Partnership Programs for State-Owned Enterprises

[16] McPherson, Michael A. "Growth of micro and small enterprises in southern Africa." Journal of development economics 48.2 (1996): 253277.

[17] Employee Relative in Small Firms: A Micro-Business Perspective Matlay, Harry. "Employee relations in small firms: A micro-business perspective." Employee relations 21.3 (1999): 285-295. 